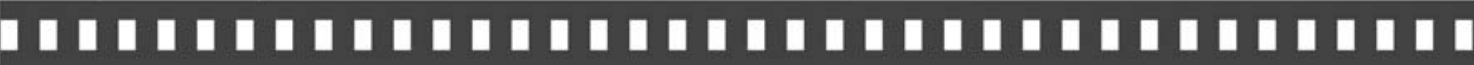 La última rosa de ayer: compromisso social e geração de sentido na obra fotográfica de Tina Modotti

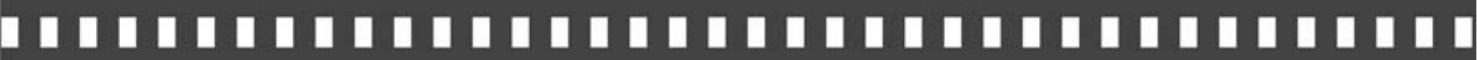

Beatriz Rodrigues Ferreira 


\title{
La última rosa de ayer: compromisso social e geração de sentido na obra fotográfica de Tina Modotti
}

La última rosa de ayer: social commitment and meaning generation in Tina Modotti's photographic works

\author{
Beatriz Rodrigues Ferreira*
}

\begin{abstract}
Resumo: Este artigo se propõe a analisar sucintamente as relações entre vida e obra da fotógrafa e militante Tina Modotti; demonstrar que seu envolvimento político no México revolucionário da década de 20 do século XX influenciou sua produção fotográfica; e estudar as fronteiras entre o envolvimento político-social e a produção de sentido na-e através da-imagem fotográfica. Para tanto, analisa algumas imagens produzidas por ela no período em que, ao mesmo tempo, se familiarizava com a fotografia e estreitava sua ligação com o Partido Comunista do México.
\end{abstract}

Palavras-chave: fotografia; fotografia de compromisso social; Tina Modotti; México.

\begin{abstract}
This article intends to briefly analyze the connections between life and works of photographer and militant Tina Modotti; demonstrate that her political involvement in revolutionary Mexico of the 1920's influenced her photographical production; and study the boundaries between social-political involvement and production of meaning in the-and through the - photographic image. To achieve that, an analysis is provided on some of her images produced in the period in which she both became acquainted with photography and narrowed her ties with Mexico's Communist Party.
\end{abstract}

Key-words: photography; social commitment photography; Tina Modotti; México.

\footnotetext{
* Licenciada em Filosofia pela Universidade Federal de Pelotas (UFPEL). Bacharel em História pela Fundação Universidade Federal do Rio Grande (FURG). Membro do grupo de pesquisa Educação e contemporaneidade: experimentações com arte e filosofia, junto ao CEFET-RS e à UFPEL, vinculado ao CNPq.
} 
"La fotografia es a lo sumo uma pequeña voz; pero em ocasiones - no siempre, por cierto ocurre que una solo foto, hasta um conjunto, seduce nuestros sentidos al punto de desembocar em uma toma de consciencia.

Todo depiende del que mira: algunas fotografias suscitan tal emoción que engendran una reflexión”

François Soulages

\section{Introdução}

Inicialmente, é necessária uma breve introdução sobre a vida de Tina Modotti, uma pequena contextualização de suas vivências, para posteriormente analisar algumas de suas obras. Isto se torna compreensível na medida em que o conhecimento de sua produção - principalmente no Brasil - dá-se numa proporção inversa à importância de sua obra na história da fotografia.

Assunta Adelaide Luigia Modotti, ou “Tina”, teve uma vida multifacetada: italiana, nascida em 1896, cresceu em um ambiente de poucos recursos, e, ainda criança, mudou-se para os Estados Unidos com o pai. Jovem e tentando a vida como atriz, teve algumas experiências em Hollywood no início dos anos 20, período em que conheceu o fotógrafo Edward Weston, de quem se tornou ajudante, discípula e amante. Em suas “expedições” fotográficas, Weston foi amparado por Tina durante anos, e esta se dedicava a carregar os equipamentos e a ajudar no processo de revelação do material produzido, além de organizar e administrar sua casa. Neste âmbito, a parceria formada foi determinante na obra de Weston, bem como na vida de Tina, principalmente pelo desejo que os moveu: conhecer e fotografar o México, para onde partiram no ano de 1923. 
Esta viagem foi uma espécie de ritual de passagem na vida de ambos, pois marcou o período em que Weston faz o seu balanço estético ${ }^{1}$, e também o período em que Tina, mobilizada pelos encontros estabelecidos no círculo artístico mexicano ${ }^{2}$, iniciou o seu envolvimento mais direto com a produção fotográfica, chegando a algumas de suas imagens fazerem parte de exposições de Weston, no México.

Com as relações entre Tina e o círculo artístico revolucionário se estreitando, o rompimento com Weston - que viviam um "romance aberto" - se tornou iminente, na medida em que para ele a arte não podia ter envolvimento político. A proposta de Tina não era a de que toda arte deveria ser essencialmente “panfletária”, mas de que através dela o artista tinha que expressar suas opiniões e as idéias em que acreditava. Assim, assumiu em sua produção o desenvolvimento estético e lingüístico que aprendeu com Weston para aliá-los a um comprometimento social, dado através dos temas - recortes espaçostemporais que escolheu retratar - como se pode notar nesta imagem (figura 1):

\footnotetext{
${ }^{1}$ Neste período Weston foi se distanciando da fotografia pictorialista, cuja base era a escolha de temas romantizados e de técnicas com resultados próximos aos efeitos da pintura da época, para trabalhar com a dessacralização do corpo feminino, através da fotografia de nus, bem como com a fotografia de objetos e pessoas em close. Segundo Braune (2000, p.69), "o close constituiu-se numa das formas de desarticulação do espaço perspectivo. A visão habitual do homem, que era global e distanciada, de modo a corresponder ao modelo imposto desde o Renascimento, encontra o seu contraponto no close, ao compreender essencialmente um fragmento de algo, exige uma maior atividade do olhar, induz a uma maior participação do espectador no desvendar dos detalhes”. E, segundo Weston (1997, p.36), “C'est l'agression visuelle permenente qu'impose le Mexique qui stimulent son oeuvre."

${ }^{2} \mathrm{O}$ período foi marcado pelo Movimento Muralista, vertente artística que agregava pintura, escultura e arquitetura, no início do século XX. A revolução mexicana de 1910 tem um papel decisivo na formação estética deste período, pois este movimento, liderado por nomes como o de Diego Rivera, José Clemente Orozco e Davi Alfaro Siqueiros, tinha como traço fundamental a produção de uma arte voltada para o povo mexicano - que representasse sua vida, suas histórias e valores, tendo, assim, a arte como um importante aliado para a intervenção social e política. Foi a partir do contato com o cenário artístico-cultural mexicano que Tina conheceu Diego Rivera, Xavier Guerrero, Siqueiros, Frida Khalo, Pablo Neruda, Maiakóvski, dentre outros que tiveram grande importância em sua vida.
} 


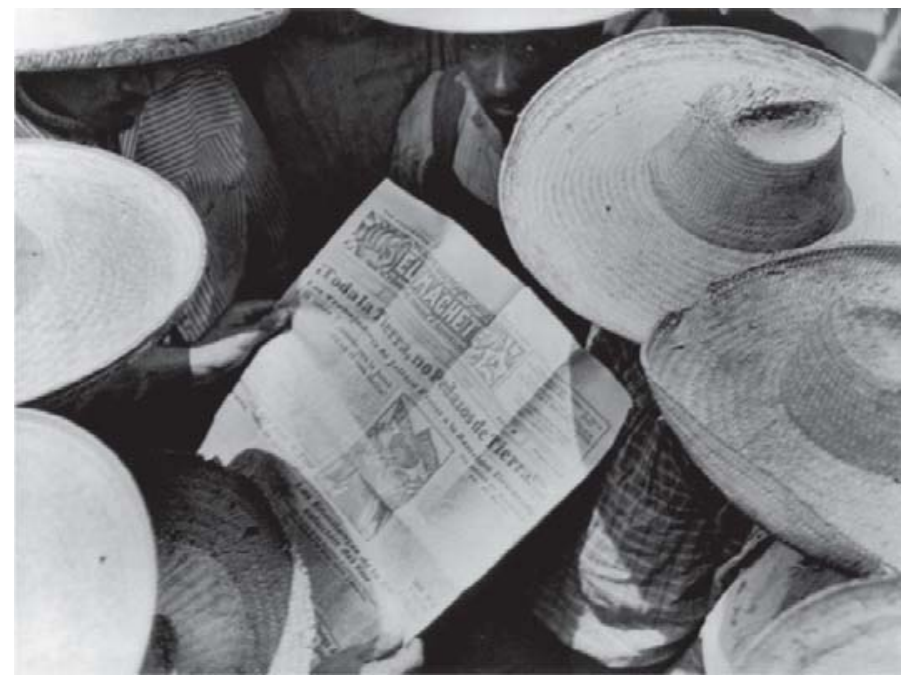

Figura 1 - Mexican peasants reading El Machete (1928)

Foto: Tina Modotti

Fonte: Hooks (2002)

Nesta imagem pode-se perceber alguns elementos que referenciam o grupo social campesino mexicano, como os chapéus e as camisas, por exemplo. Tem-se também uma pessoa lendo a primeira capa do jornal $E l$ Machete, que não por acaso ocupa o centro da imagem, já que este era conhecido por ser um jornal comprometido com as causas populares do período, além de ser o meio de informação que apoiava o movimento cultural revolucionário daquela época - e para o qual Tina trabalhou por um período. A manchete diz “toda la tierra, no pedazos de tierra”, o que corresponde a uma luta secular no México, pelo término dos latifúndios. Esta composição pode denotar a intencionalidade comunicacional desta imagem: chapéus que indicam a igualdade entre as pessoas que compõem o quadro e o extra-quadro (pois a imagem suscita outros chapéus, outras pessoas na mesma situação, e, assim, com os mesmos interesses), uma unidade definida pela luta a que se propõe - a luta pela terra e pela dignidade campesina no México pós-revolucionário. É interessante notar o modo como um dos homens mostra seu rosto e se impõe ao olhar da fotógrafa - este homem nos olha, de alguma forma. 
A influência de Edward Weston na obra de Tina Modotti é óbvia, no que tange a sua postura em se distanciar dos fotógrafos que buscam por “efeitos artísticos” na imagem fotográfica, que tenham como base imitações de outros modos de expressão gráficas, como a pintura - o pictorialismo. Para Tina, a câmera fotográfica atuava como uma ferramenta, tal como afirmou, em dois momentos:

I consider myself a photographer, nothing more. If my photographs differ from that which is usually done in this field, it is precisely because I try to produce not art but honest photographs. ${ }^{3}$ (MODOTTI apud HOOKS, 2002, p.12).

Photography, precisely because it can only be produced in the present and because it is based on what exists objectively before the camera, takes its place as the most satisfactory medium for registering objective life in all its aspects, and from this comes its documental value. If to this is added sensibility and understanding and, above all, a clear orientation as to the place it should have in the field of historical development, I believe that the result is something worthy of a place in social production, to witch we should all contribute. ${ }^{4}$ (MODOTTI apud HOOKS, 2002, p.12).

É certo que a imagem anterior já apresenta Tina com um estilo desenvolvido. Seria interessante, então, revisitar algumas imagens que mostrem sua trajetória, e a busca por elementos éticos e estéticos que dêem conta daquilo que veio a ser o seu tema corrente.

Esta imagem (figura 2) foi feita no ano de 1924, ainda nos primeiros meses em que Tina e Edward se encontravam no México. Em meio a uma intensa vida social, ambos não deixavam o trabalho fotográfico de lado.

\footnotetext{
${ }^{3}$ Tradução livre: "Eu me considero uma fotógrafa, nada mais. Se minhas fotografias diferem daquelas que são normalmente feitas neste campo, é precisamente porque eu tento produzir não arte, mas fotografias honestas.”

${ }^{4}$ Tradução livre: "A fotografia, precisamente porque só pode ser produzida no presente, e porque é baseada naquilo que existe objetivamente à frente da câmera, tem a propriedade de ser o meio mais satisfatório de registrar objetivamente a vida em todos os seus aspectos, e disso decorre o seu valor documental. Se à fotografia são adicionadas sensibilidade e compreensão e, acima de tudo, uma clara orientação de qual lugar ela deveria ter no campo do desenvolvimento histórico, eu acredito que o resultado é algo digno de respeito na produção social, para a qual todos nós devemos contribuir.”
} 
Quando da ocasião das apresentações de um circo russo - que se encontrava próximo ao local onde moravam, na Cidade do México ambos partiram para fazer algumas imagens. Tina, além de ajudante de Weston, era sua aprendiz. Embora estivesse ainda em um estágio inicial de suas experimentações fotográficas, já é possível apontar que neste período ela estava desenvolvendo um olhar próprio, que não primava apenas pelo exercício da forma - posto que as imagens de Weston para esta série são compostas apenas por abstrações ${ }^{5}$ - mas que mostravam uma preocupação com a forma, aliada à abertura ao contexto social.

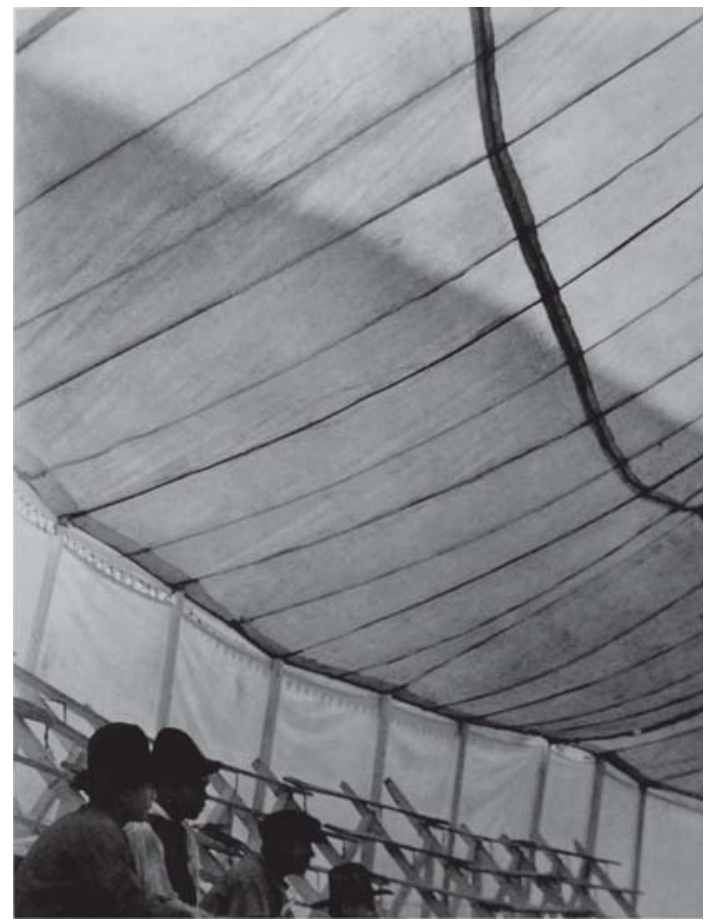

Figura 2 - Tenda de circo (1924)

Foto: Tina Modotti

Fonte: Hooks (2002)

${ }^{5}$ Amy Conger (apud BARCKHAUSEN-CANALE, 1989, p.77) diz que "já em março de 1924 Modotti passou a incluir em suas fotos pessoas, por sinal desconhecidas. Ela pode ter percebido que isso dava à composição alguma coisa específica, ajudando a colocá-la no espaço e no tempo. Com certeza ela não aprendeu isso com Weston, que era incapaz de fotografar na rua”. 
Na imagem, percebe-se uma composição formada por grafismos. Mas como um circo é formado, também, pela dimensão da sociabilidade, Tina a assumiu como um elemento constituinte da imagem, no que tange a sua estética - a criação da perspectiva, já que o jogo de arquibancadas e pessoas direciona a leitura da imagem - bem como de criação de sentido.

Observa-se a imagem seguinte (figura 3):

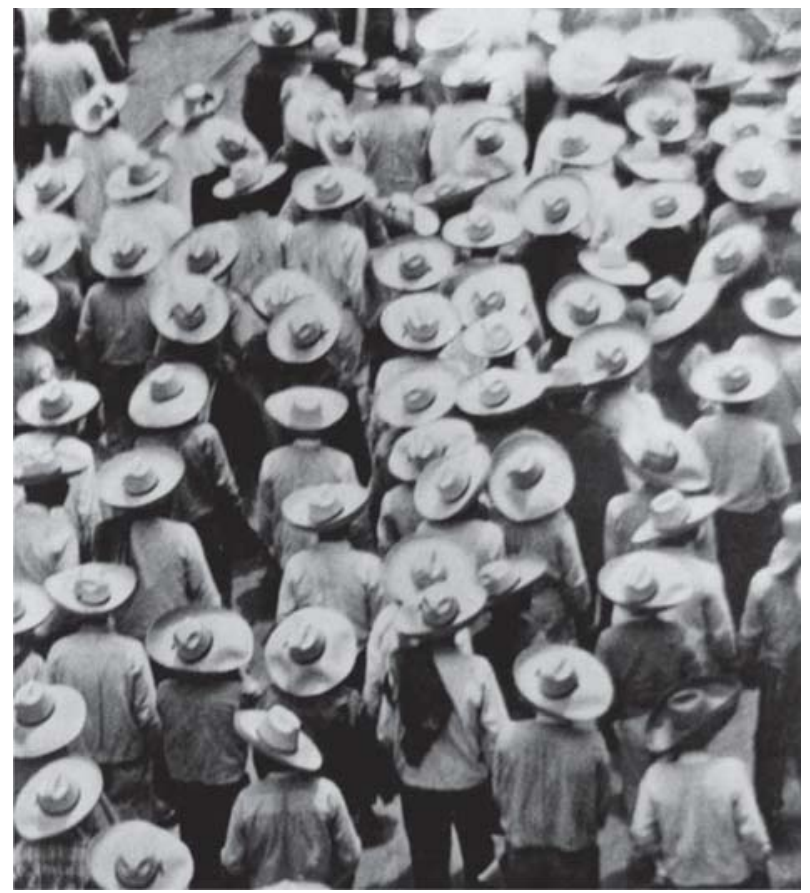

Figura 3 - Manifestação de trabalhadores - Cidade do México (1926)

Foto: Tina Modotti

Fonte: Hooks (2002)

Pode-se pensar que as relações entre arte e vida na obra de Tina Modotti se perfazem mediante uma série de fatores: a sua infância pobre na Itália, a sensibilidade à realidade social mexicana, sua oposição ao fascismo, seu envolvimento com os artistas do Movimento Muralista, e, posteriormente, seu envolvimento com o Partido Comunista. Todos 
tiveram uma forte influência na formação do seu olhar. Em sua obra é possível afirmar, então, que a composição da imagem fotográfica está imersa em uma concepção política de mundo, e se direciona a dar conta destas realidades marginalizadas, visíveis, e funciona, assim, como um instrumento de luta.

Como ela tinha o interesse de trabalhar a fotografia de outra maneira, em que o século XX não fosse visto "com o olhar míope do século XVIII” (MODOTTI apud HOOKS, 2002, p.12), seu trabalho começava a encontrar uma expressão mais concreta. Na sua arte estava impressa a realidade do México dos anos 20, e esta imagem é uma das primeiras em que claramente tentou unir os dois temas que lhe ocupavam existencialmente: a fotografia e a política.

Esta imagem (figura 3) foi feita a partir de um telhado, com a sua câmera portátil, adquirida havia pouco tempo. Do alto, direcionou o olhar para a marcha de camponeses, com seus chapéus de palha, símbolo do México rural e da reforma agrária naquele país. Foi publicada na revista Mexican Folkways, e é uma imagem bastante emblemática neste contexto de ligar a arte com a política, pois dá conta de vários sentidos.

Em primeiro lugar, o jogo de luz e sombras, que propõe um senso muito forte de movimento à imagem; em segundo, a questão simbólica, tendo nos chapéus um elemento da luta camponesa, e a uniformidade, a homogeneidade, conotando que a união e a igualdade estão presentes neste movimento, que todos lutam por - e se direcionam a - um sentido comum: antiimperialista e voltado para os direitos dos trabalhadores. Segundo Hooks (1997, p.137):

Essa fotografia marca o início do que se tornou o leitmotif da fotografia de Tina: a fusão do formalismo e a preocupação com a composição, com seu crescente interesse e envolvimento na política revolucionária mexicana.

Como alusão ao trabalho, passa-se a duas outras imagens (figuras 4 e 5) bastante significativas na obra da fotógrafa: 


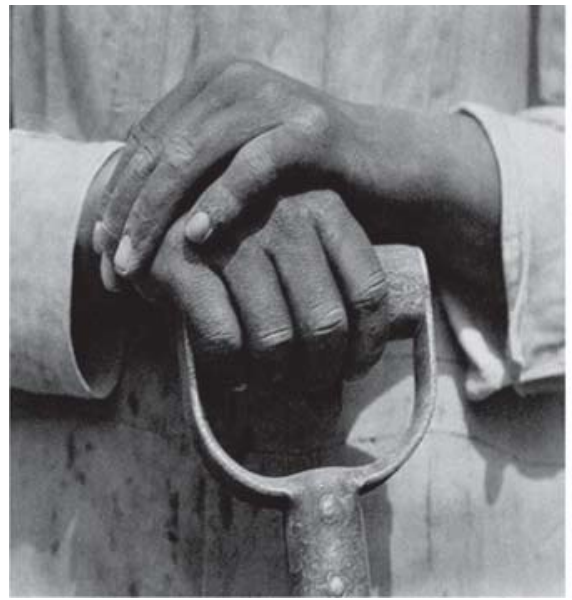

Figura 4 - Hands holding tool (1927)

Foto: Tina Modotti

Fonte: Hooks (2002)

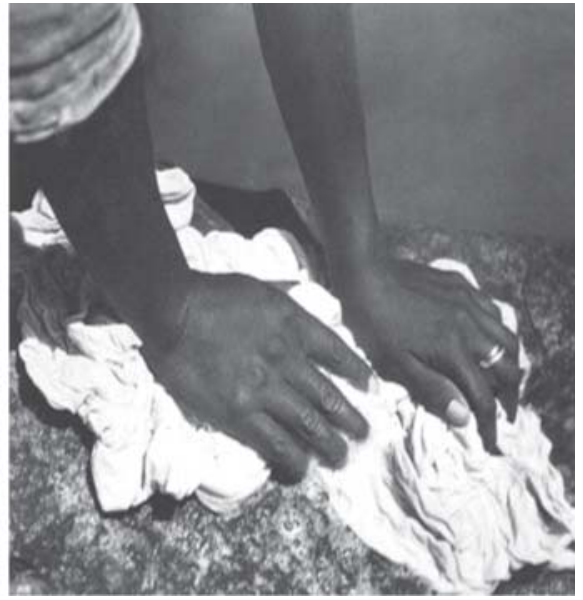

Figura 5 - Handwashing (1927)

Foto: Tina Modotti

Fonte: Hooks (2002)

Nestas duas imagens se têm as representações de mãos de pessoas que trabalham, e, nota-se pela sua aparência (calosidades), e pelos instrumentos que portam, os signos das atividades sociais que desempenham. Foram feitas no mesmo ano, de grupos sociais semelhantes, mas com a distinção de gênero: percebe-se que em sua obra existe uma grande incidência da imagem feminina ligada ao trabalho e à dignidade, 0 que tem íntima relação com o ideal de liberdade da mulher que preconizava já naquela época, sendo duramente atacada em alguns momentos pela sociedade mexicana. Na obra de Tina Modotti, a mulher é percebida como ativa e dotada de percepções próprias de sua condição.

Como pessoa que teve um papel importante na divulgação dos ideais revolucionários naquele período, no que tange à geração de sentido em sua obra, é interessante considerá-la como uma fotógrafa importante na história da fotografia não apenas pelo quanto suas imagens foram capazes de servir como instrumento de propagação das idéias comunistas, pelo apelo à igualdade social, mas também pelo desenvolvimento estético, e a formação do olhar que sua obra é capaz de suscitar. Acima de tudo, com suas fotografias, Tina Modotti já colocava em questão, na década de 20, algo ainda discutido na contemporaneidade: a impossibilidade de uma 
produção fotográfica neutra, na medida em que, como recorte, a fotografia é, além de uma forma particular de ver o mundo, uma forma particular de agir sobre o mundo. Machado (1984, p.14), afirma que:

Ao representar, ao construir sistemas para operacionalizar o mundo, ao articular as relações em que se acha mergulhado, o homem necessariamente [...] interfere, interpreta e altera o objeto representado, porque a ação do sujeito é sempre produtiva e não pode ser reduzida à atitude do espectador passivo.

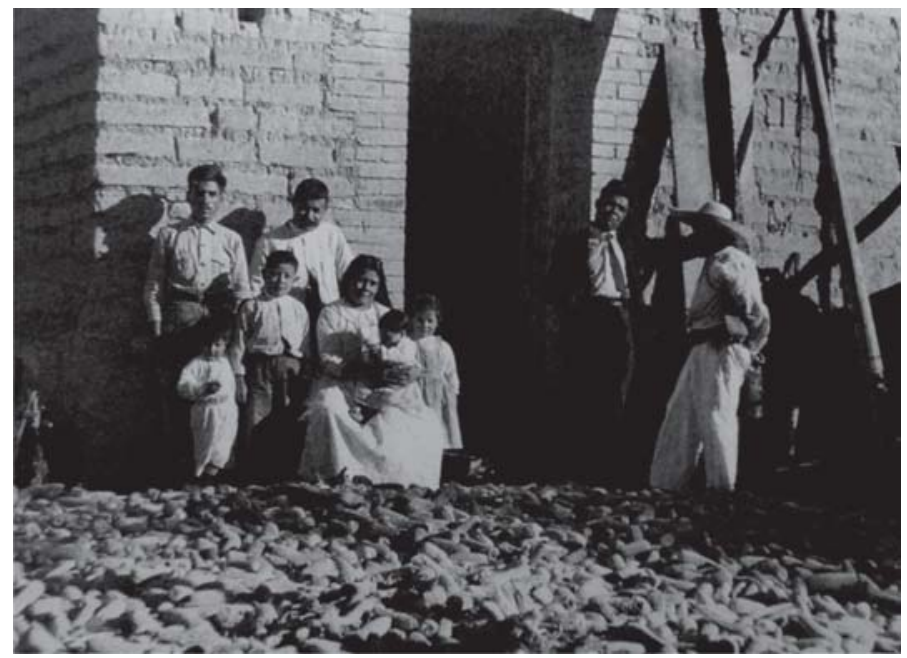

Figura 6 - Família Camponesa em Veracruz (1927)

Foto: Tina Modotti

Fonte: Hooks (2002)

Nesta imagem (figura 6), temos a tão difundida pose familiar sendo desmistificada da sua noção tradicional de representação. O que é normalmente ensaiado e forjado, de modo a manter para a posteridade uma imagem idealizada que um grupo ou indivíduo tem de si, é tomado sua simplicidade, no contexto ao qual pertence o grupo que está sendo retratado. Embora as pessoas que compõem a foto estejam claramente alinhadas, a fotógrafa criou uma perspectiva em que as espigas de milho que praticamente encobrem o terreno estejam em primeiro plano, mantendo 
como referência simbólica o local de onde estas pessoas provêm: um ambiente rural, mantido com simplicidade, a partir da cultura do milho. Sabe-se que este figura como um dos expoentes milenares que confere a identidade social daquele povo, já que era um dos principais produtos cultivados na cultura pré-colombiana da civilização maia. Assim, este elemento foi também por ela explorado em outras composições, como nas imagens conhecidas em que vários ícones de identidade (o milho, novamente, a viola dos Mariachis) estão relacionados aos símbolos do comunismo (como a foice e o martelo, que simbolizam a luta dos trabalhadores rurais e do operariado industrial, ou com cinturões de balas, que indiciam a revolução armada).

Coloca-se em foco outra imagem produzida por Tina Modotti (figura 7):

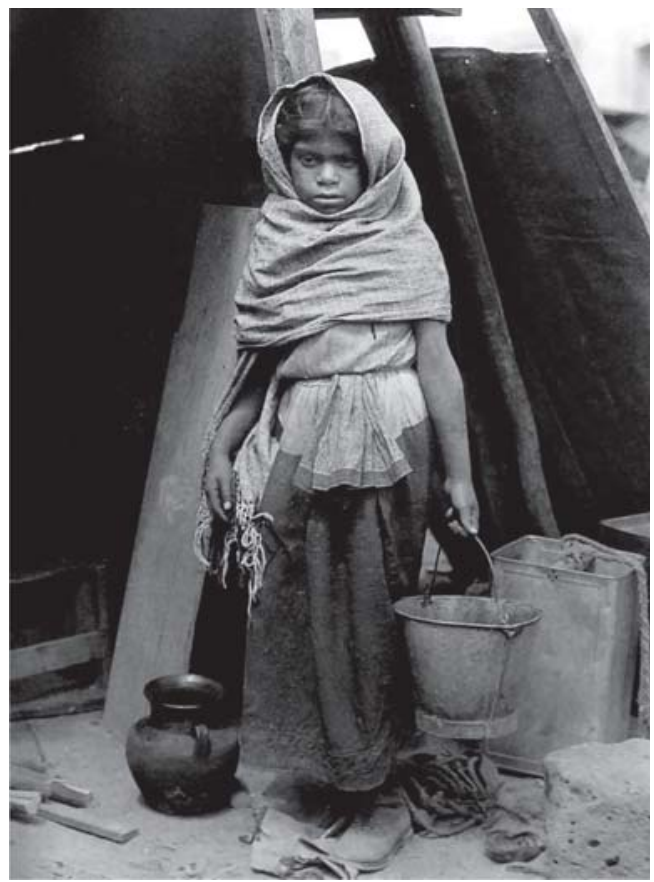

Figura 7 - Filha de ferroviário (1928)

Foto: Tina Modotti

Fonte: Hooks (2002) 
Nesta fotografia, tem-se uma composição bastante contundente para a época. Tina fez uma imagem de uma criança em sua mais crua realidade: a miserabilidade e o trabalho. É uma imagem típica de um cotidiano encoberto, que não havia conquistado o estatuto de imagem perante a sociedade. Sua fotografia, neste contexto, deixa de ser um mero exercício aprazível dos sentidos, e propõe uma ruptura com o padrão de visibilidade da época. Em períodos de revoluções que se baseavam nos ideais de grupos trabalhadores, a estética do gesto presente nesta fotografia (a sutileza como a menina toca o manto que encobre seu cabelo, em contraposição à força que dispõe para segurar o balde, e o seu olhar distante) atenta para o fato de haver a necessidade de modificação das estruturas sociais vigentes, minimamente por uma questão humanitária - a sobrevivência.

Sua sensibilidade para com a dor alheia é confirmada em relatos como os do diário de Edward Weston, quando ele e ela encontraram uma menina, chamada Carmen, convidada a viver com o casal.

Estava sentada na calçada de cimento, encostada na coluna de um pórtico, diante de um tabuleiro cheio de sementes de abóbora. Ela dormitava e acordava, de vez em quando, para vender maquinalmente uma dúzia de sementes por um centavo. Depois, suas pálpebras pesadas voltavam a fechar-se e, à luz dos candeeiros, seu rosto pálido adquiria novamente estas formas agudas. (WESTON apud BARCKHAUSEN-CANALE, 1989, p. 75-76).

Essa afecção que Tina Modotti tinha por estas realidades sociais não é algo gratuito. Barckhausen-Canale (1989), biógrafa da fotógrafa, afirma que:

Ao gravar, nas suas fotos de crianças mexicanas, testemunhos inquietantes de pobreza e desespero - não o fez como uma repórter indiferente, mas sim como uma pessoa que sofria com o que via e retratava. [...] A afetação pela pobreza que está presente na obra de Tina pode ter relação, também, com as lembranças das privações 
que vivera em sua infância, e do sofrimento vivido por seus irmãos menores. Sobre esta relação entre vivências que constituem a sua sensibilidade para com o mundo, e que, portanto, compõem a sua obra, uma passagem de entrevista a um jornal local é bastante significativa: “[O México] me faz lembrar a Itália. É por isso que quando estou no México me sinto mexicana. Nos Estados-Unidos, ao contrário, sentia-me em um país estrangeiro.” (apud HOOKS, 1997, p.104).

Sua preocupação social, utilizando a fotografia como um motor de transformação, certamente contribuiu para que trabalhos como os de Sebastião Salgado fossem aceitos e aclamados na contemporaneidade. Percebe-se, pois, que as relações entre arte e vida estão muito presentes em Tina, e estas surgem para ela como um problema, uma reflexão, tal como o é apresentado na carta de 7 de julho de 1925, enviada a Edward Weston:

[...] Falando de mim, pessoalmente, não posso resolver o problema da vida perdendo-me no da arte - como você aconselhou-me certa vez. Não é só o fato de que eu não consigo fazê-lo: sinto, mesmo, que o problema da vida afeta o da arte; [...] em meu caso, a vida combate constantemente pelo predomínio, e a arte, naturalmente, sofre por causa disso. Com o termo "arte" refiro-me à criação, de todo o tipo. Você poderia dizer que, se em mim o elemento da vida é mais forte do que o da arte, eu devo resignarme e tirar disso o maior proveito. Mas eu não posso aceitar a vida assim como ela é, demasiadamente caótica e inconsciente. Daí minha resistência, minha luta, meu desejo constante de adaptar a vida a meu temperamento e as minhas necessidades. Em outras palavras, eu incluo arte demais, energia demais em minha vida e, por causa disso, não me sobra nada para dar à arte. (MODOTTI apud BARCKHAUSEN-CANALE, 1989, p. 93-94).

Se a obra de Tina tem uma relação muito grande com a vida, é possível perceber que para ela a própria relação de "vida como obra de arte” é bastante explicitada ao longo da sua criação e da sua trajetória. Não se trata apenas de construir uma arte que tenha relação com valores éticos, mas de construir a vida esteticamente: viver é criar possibilidades 
de diferença mediante afecção ${ }^{6}$. E ela criou novas possibilidades para a percepção sobre o cotidiano a partir da constituição subjetiva do olhar que colocou em suas imagens. Como afirma Deleuze (1992, p.126), “o estilo, num grande escrito, é sempre também um estilo de vida, de nenhum modo algo pessoal, mas a invenção de uma possibilidade de vida, de um modo de existência”.

Se perceber se relaciona com a formação de idéia sobre algo capturado pelos sentidos, o que é apresentado na obra de Tina Modotti não se dá apenas por uma noção cognitiva: ela não apenas reage à realidade com a qual se defronta. Ela se afeta, e ao se afetar, deseja modificá-la. É preciso viver algo com intensidade para disso se apropriar. Somente alguém que se apropria de algo - neste caso, de uma realidade - pode ressignificá-lo.

De modo a concluir as análises, passa-se a uma última fotografia (figura 8):

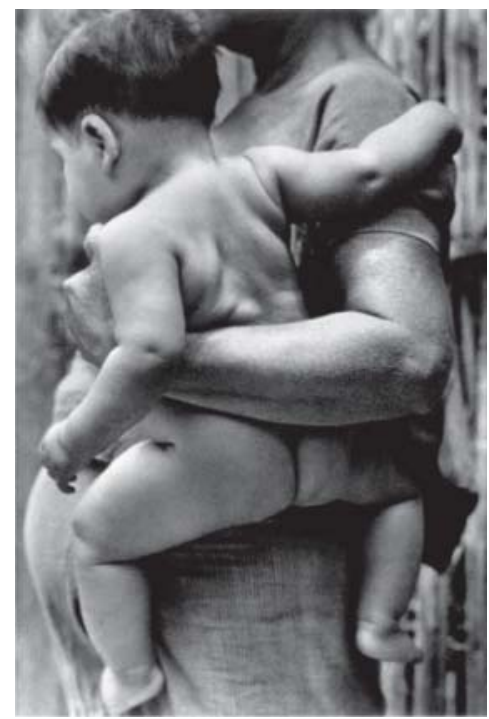

Figura 8 - Mother-Child (1929)

Foto: Tina Modotti

Fonte: Hooks ( 2002)

${ }^{6}$ Deleuze e Guattari (1997b, p.225) definem afecto: “Não é que um se transforme no outro, mas algo passa de um ao outro. É uma zona de indeterminação, de indiscernibilidade, como se coisas, animais e pessoas tivessem atingido, em cada caso, este ponto que precede imediatamente sua diferenciação natural. É o que se chama um afecto.” 
Nesta imagem, tem-se a ligação íntima entre mãe e filho, através do gesto de possibilitar o movimento àquele que ainda não caminha por si, bem como da gestação ainda em curso. A mãe aparece como mais uma faceta da figura feminina, progenitora; aquela com quem se vivencia as primeiras experiências do mundo, que, apesar de se inserir como figura ativa no processo de luta social, não se abstém da sua relação com a terra e com a geração da vida. Novamente figuras com identidade, mas sem identificação: esta mãe e este filho não têm nome, eles podem ser qualquer um, o que significa também que somos todos nós. Esta, decididamente, não é uma passividade do olhar, pois a fotógrafa, ao isolar seus corpos no enquadramento, propôs-lhes uma perspectiva universal sobre a figura do feminino. Como em Soulages (2005, p.41), "no hay um acontecimiento que preexista a su reconocimiento. No hay tanto um objeto-realidad por fotografiar como um sujeto que transforma um fenômeno visible em signo de um objeto por fotografiar”. Assim, não é de forma neutra que Tina Modotti retrata um grupo social, dando ênfase ao gênero feminino.

É possível dizer, então, que suas fotografias não são jornalísticas, pois através delas não se preocupou em atestar um estatuto de verdade. Com elas, expressou a sua visão de mundo, e esta de modo algum teve como princípio a manutenção das estruturas de poder vigentes. Assim, é por meio de uma preocupação estética muito forte e de um posicionamento político, refletidos em sua produção artística, que a fotógrafa não apenas retratou a realidade campesina com a qual se relacionou, mas buscou que suas fotografias pudessem se tornar meios de contestação da naturalidade desta realidade. Na sua obra, percebese o papel que a arte tem de propor a reflexão, de instigar o pensamento, e de contestar as formas naturalizadas do olhar.

Assim, através de sua obra além de ser tangível pensar o poder da imagem como elemento de difusão de idéias, pelo compromisso social e pela intencionalidade comunicacional que ela assumia (manifestação, denúncia e proposta de modificação de realidades), é possível definir Tina Modotti como uma das primeiras fotodocumentaristas mulheres, 
não porque tenha feito um estudo preliminar sobre o grupo que pretendia retratar, mas porque convivia diretamente com este grupo, identificavase com sua luta, e decidiu registrá-lo mostrando o cotidiano do homem campesino e as suas relações com o espaço em que este vive em toda a sua beleza, e nos seus aspectos mais humanos. Neste sentido, pode-se considerá-la, também, como uma fotógrafa humanista.

De acordo com Machado (1984), é no espaço intersticial da técnica que ocorrem os maiores conflitos sociais, pois assumi-la é uma forma de deter meios econômicos de se fazer expor, e os grupos sociais menos favorecidos não têm possibilidade de se fazer dizer, de construir a sua imagem - ou a têm dificultada, tornando-se quase impossível, e principalmente neste período, de se auto-referenciarem. A fotografia, basicamente então utilizada para disseminar os valores e os modos de representação de uma burguesia incipiente, foi utilizada por Tina Modotti na década de 20 não somente como meio de retratar a realidade cotidiana dos campesinos mexicanos, mas como uma máquina de guerra, no sentido definido por Deleuze (1992) . Máquina de guerra como algo que, por meio de afecção, promove um abalo nas estruturas normativas e normalizantes de ver a vida. A máquina de guerra está apontada, pois, aos conceitos dominantes e aos lugares comuns, onde resistir é também criar. Isto porque suas fotografias foram capazes de mobilizar um reconhecimento do cotidiano deste grupo social que era nivelado, e promovia, através deste confronto com a imagem que se pretende negar, a reflexão sobre toda uma sociedade deparada com suas características mais vitais: a sua ascendência indígena maia, a relação íntima com a terra de seus antepassados, e a "síndrome do colonizado” de uma sociedade que assumia valores completamente alheios a sua cultura milenar como seus.

\footnotetext{
${ }^{7}$ Segundo o filósofo, as máquinas de guerra não se definem pela 'guerra' no sentido usual que o termo é utilizado, mas "por uma certa maneira de ocupar, de preencher o espaço-tempo, ou de inventar novos espaços-tempos: os movimentos revolucionários [...], mas também movimentos artísticos são máquinas de guerra”. (DELEUZE, 1992, p.212).
} 
Isto tudo contribuiu para a formação de uma arte fotográfica nômade, que não estava de acordo com os princípios do estado oligárquico da época. Uma máquina de guerra porque lutava contra os regimes vigentes de visibilidade, por meio de uma criação contestadora. Uma arte que dá a pensar, e que trabalhou o pensamento como heterogênese. Pois, como é definido por Deleuze e Guattari (1997b, p.227):

O artista é mostrador de afectos, inventor de afectos, criador de afectos, em relação com os perceptos ou as visões que nos dá. Não é somente em sua obra que ele os cria, ele nos dá para nós e nos faz transformarmos com eles, ele nos apanha no composto.

Uma arte que põe o pensamento em fluxo é, pois, aquela que provoca inquietações, que abala as certezas de mundo, e que propõe novos modos de ver aquilo que está socialmente aceito como natural. Se Foucault (apud DELEUZE, 1992) falava que era preciso "rachar as palavras” para delas retirar os seus enunciados, na fotografia é necessário encontrar um entre, uma dobra que dê conta do regime de visibilidade no qual a imagem se manifesta, ou ao qual ela anuncia. Em última análise, está-se se direcionando para a questão do olhar, à sua constituição, que está tanto para a estética quanto para a ética, e, no caso de Tina Modotti, também para uma postura política.

Se, como afirma Freund (1976, p.7):

Cada momento histórico presencia el nacimiento de unos particulares modos de expresión artística, que corresponden al carácter político, a las maneras de pensar y a los gustos de la época. [y] El gusto no es una manifestación inexplicable de la naturaleza humana, sino que se forma en función de unas condiciones de vida muy definidas que caracterizan la estructura social en cada etapa de su evolución.

Então, não é possível destituir a formação do olhar da fotógrafa à sua experiência no México, às relações que neste país estabeleceu, e às 
lutas às quais se filiou. Em síntese, as relações entre vida e obra de Tina Modotti são muito estreitas, assim como a relação entre arte e vida. O próprio título deste estudo é uma alusão ao epitáfio da fotógrafa - escrito por Pablo Neruda - que diz:

Tina Modotti, hermana, no duermes, no, no duermes.

Tal vez tu corazón oye crecer la última rosa De ayer, la última rosa de ayer, la nueva rosa.

Descansa dulcemente, hermana. Puro es tu dulce nombre, pura es tu frágil vida. De abeja, sombra, fuego, nieve, silencio, espuma,

De acero, línea, polen se construyó tu férrea.

\section{Considerações finais}

Conclui-se estas breves reflexões acerca da obra de Tina Modotti com a questão da sensibilidade ligada à produção e à recepção artísticas, tendo, neste caso, como foco a produção fotográfica. Caso a fotografia seja tomada apenas como meio de informação/ comunicação, poderá se estar incorrendo em uma simplificação das potencialidades que ela - enquanto linguagem formada a partir de signos não verbais - possa ter. Isto porque suas fotografias não se encerram na realidade mexicana dos anos 20 do século passado, elas não apenas "informam”. Embora referenciem e documentem um tempo e um espaço específico - um instante, por assim dizer - elas são capazes de nos relembrar que as distinções sociais estão presentes ainda hoje na nossa sociedade, que o trabalho ainda é objeto de exploração, que as mulheres ainda sofrem tratamentos desiguais e que mesmo os esquecimentos sociais ${ }^{8}$ são frutos de propostas sutis de imposição de modos de ver, e viver.

${ }^{8}$ Vide historiadores da memória, como Pierre Nora e Michel Pollak. 
Assim como suas imagens são capazes de sensibilizar um olhar mais atento às questões sociais, é interessante ressaltar que só se reflete sobre aquilo que primeiramente se sensibilizou. Aquilo que produz potências de mobilização pode se tornar uma forma de contestar a naturalização do olhar, e propor diferentes modos de ver, e, conseqüentemente, de agir socialmente.

Para que a fotografia não se contenha em informar, para que não perca esta potência de revelar outras possibilidades, para que no, no duermas, no duermas...

\section{Referências}

BARCKHAUSEN-CANALE, Christiane. No rastro de Tina Modotti. São Paulo: Alfa-Ômega, 1989.

BRAUNE, Fernando. O surrealismo e a estética fotográfica. Rio de Janeiro: 7Letras, 2000.

DELEUZE, Gilles. Conversações. São Paulo: Ed. 34, 1992.

DELEUZE, Gilles; GUATTARI, Félix. Mil Platôs: capitalismo e esquizofrenia. São Paulo: Ed. 34, 1997a. v.5.

. Percepto, afecto e conceito. In: . O que é a

filosofia? 2.ed. São Paulo: Ed. 34, 1997b. p. 213-255.

FREUND, Gisèle. La fotografía como documento social. Barcelona: G. Gili, 1976.

HOOKS, Margaret. Tina Modotti. Londres: Phaidon, 2002. 
. Tina Modotti: fotógrafa e revolucionária. Rio de Janeiro: José Olympio, 1997.

MACHADO, Arlindo. A ilusão especular: introdução à fotografia. São Paulo: Brasiliense, 1984.

SOULAGES, François. Estética de la fotografía. Buenos Aires: La Marca, 2005.

WESTON, Edward. Aperture masters of photography. New York: Könemann, 1997. 
